\title{
МАТРИЧНАЯ ЛЕКАРСТВЕННАЯ ФОРМА ПРОЛОНГИРОВАННОГО ДЕЙСТВИЯ С НАТРИЯ ЦЕФАТОКСИМОМ
}

\author{
Т.В. Крюк, Т.Г. Тюрина, Т.А. Кудрявцева \\ ГУ «Институт физико-органической химии и углехимии им. Л.М. Литвиненко», \\ 283114, г. Донецк, ул. Р. Люксембург, 70.
}

DOI: 10.19163/MedChemRussia2021-2021-487

E-mail:ktvl2010@mail.ru

Перспективным направлением создания новых эффективных лекарственных веществ (ЛВ) с пролонгированным действием считается получение полимерных форм ЛВ. С этой целью изучена возможность получения азометиновых производных на основе окисленного картофельного крахмала (содержание групп CHO 70 \%) и натрия цефатоксима (NaCFT).

Синтез проводили в водной среде при $50{ }^{\circ} \mathrm{C}$ в течение 2 ч. В этих условиях с выходом 76 \% был получен продукт, содержащий 30 мол.\% звеньев с NaCFT. Образование конъюгата подтверждено методами УФ- и ИК-спектроскопии, структура установлена с помощью ${ }^{1} \mathrm{H}$ ЯМР спектроскопии:

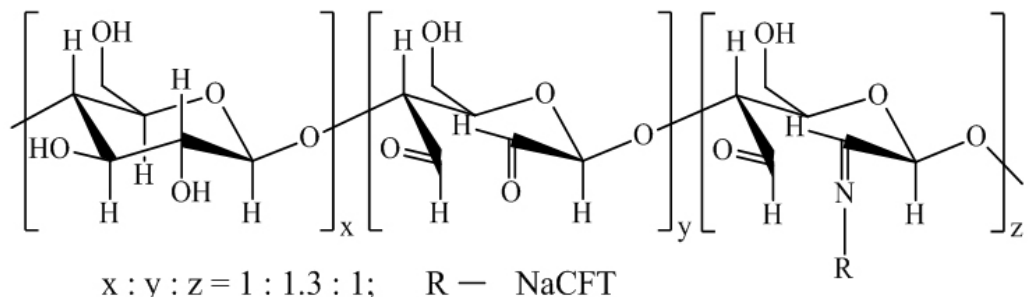

Скорость расщепления азометиновой связи между антибиотиком и полимерным носителем оценивали in vitro при $38 \pm 1{ }^{\circ} \mathrm{C}$ в Tris- $\mathrm{HCl}$ буфере (в присутствии и без химотрипсина (XТ)) и в физрастворе. Установлено, что во всех случаях профиль высвобождения имеет вид, традиционный для полимерных систем доставки лекарств (рис. 1). Более медленное выделение ЛВ наблюдается в физрастворе, присутствие фермента не оказывает влияния на скорость высвобождения.

Таким образом, синтезированный конъюгат может рассматриваться как матричная лекарственная форма с пролонгированным антибактериальным действием.

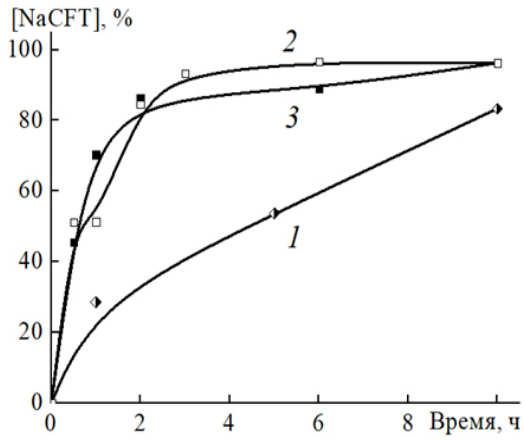

Puс. 1. Профиль высвобождения NaCFT из конъюгата в физрастворе (1), Tris-HCl буфере в присутствии (2) и без химотрипсина (3). Концентрация, моль/л: ХT - 1•10-7, конъюгат - 5•10-4. 